\title{
Author Correction: Measurement of the neutron charge radius and the role of its constituents
}

\author{
H. Atac (D, M. Constantinou (D), Z.-E. Meziani (D), M. Paolone (1) \& N. Sparveris (i)
}

Correction to: Nature Communications https://doi.org/10.1038/s41467-021-22028-z, published online 19 March 2021.

The original version of the Supplementary Information associated with this Article omitted a reference to previous work in Phys. Rev. C83, 055203 (2011). This has been added as reference [34] in Section 3 of the Supplementary Information: "The Galster is a long standing phenomenological parametrization that could adequately describe the early $\mathrm{G}_{\mathrm{E}}^{\mathrm{n}}$ data, but as recent experiments revealed ${ }^{34}$ it does not have sufficient freedom to accommodate reasonable values of the radius, without constraining or compromising the fit".

This has been corrected in the PDF and HTML versions of the Article.

Published online: 27 May 2021

\section{Additional information}

Supplementary information The online version contains supplementary material available at https://doi.org/10.1038/s41467-021-23842-1.

(c) (i) Open Access This article is licensed under a Creative Commons Attribution 4.0 International License, which permits use, sharing, adaptation, distribution and reproduction in any medium or format, as long as you give appropriate credit to the original author(s) and the source, provide a link to the Creative Commons license, and indicate if changes were made. The images or other third party material in this article are included in the article's Creative Commons license, unless indicated otherwise in a credit line to the material. If material is not included in the article's Creative Commons license and your intended use is not permitted by statutory regulation or exceeds the permitted use, you will need to obtain permission directly from the copyright holder. To view a copy of this license, visit http://creativecommons.org/licenses/by/4.0/.

(C) The Author(s) 2021 